\title{
A Measure of Victory: Go Down, Moses and the Subversion of Racial Codes
}

\author{
Abdul-Razzak Al-Barhow ${ }^{1}$ \\ ${ }^{1}$ Department of Foreign Languages, Taif University, Taif, Saudi Arabia; Department of English, University of \\ Aleppo, Aleppo, Syria \\ Correspondence: Abdul-Razzak Al-Barhow, P O Box 12359, 21944 Taif, Saudi Arabia. Tel: 966-569-902-855. \\ E-mail: arbarhow@gmail.com
}

Received: October 22, 2012 Accepted: November 12, 2012 Online Published: January 17, 2013

doi:10.5539/ells.v3n1p31 URL: http://dx.doi.org/10.5539/ells.v3n1p31

\begin{abstract}
This article studies the way white and black characters in Go Down, Moses engage with the racial codes inside the McCaslin plantation. It tries to examine the impact of William Faulkner's engagement with social change and race relations on the structure of the seven stories that make up the text of Go Down, Moses. It argues that there is a measure of triumph in the continuous attempts by both black and white characters at subverting the racial order in the southern plantation even though these attempts are quite often subverted by counter attempts at maintaining the status quo. The book achieves a "measure of victory" in the way its narrative techniques acknowledge and respect the otherness of black people and, more importantly, in the way its white and black characters maintain their determination to subvert the codes of the Southern racial ideology.
\end{abstract}

Keywords: William Faulkner, race relations, ideology, social change, Yoknapatawpha

\section{Introduction}

When William Faulkner expressed his political opinions regarding race relations and social change, he adopted the position of a gradualist and Southern moderate. Indeed, his opposition to segregation brought him threat letters, and he was even labelled "nigger lover" by some Mississippians. Sometimes, however, Faulkner's writings were controversial in the opposite way. In 1956, when he felt that there was a possibility for enforcing social change by military intervention, he said an interview: "If I have to choose between the United States government and Mississippi, then I'll choose Mississippi... As long as there is a middle road, all right, I'll be on it. But if it came to fighting I'd fight for Mississippi against the United States even if it meant going out into the street and shooting Negroes." Faulkner, however, regretted saying this, and he explained that he was drunk when he gave the interview (Meriwether \& Millgate, 1968, pp. 260-1; 265).

Faulkner's middle road, the call for peaceful and gradual change was quite paternalistic sometimes. In "A Letter to the North," he wrote, addressing "the NAACP and all the organizations who would compel immediate and unconditional integration: "Go slow now. Stop now for a time, a moment. You have the power now; you can afford to withhold for a moment the use of it as a force..." (Faulkner, 1967, p. 87). When Faulkner was once asked to specify a period for making the desired change, he talked about three hundred years (Gray, 1994, p. 39). Even though Faulkner's position might be appreciated better when read within his social and historical circumstances, it is important to stress that it was Faulkner's divided self between loyalty to his state and region and his desire to bring social change and stop racial oppression that helped force his novels into life. It is in the novels themselves that we can appreciate Faulkner's literary response to race relations.

\section{Discussion}

Go Down, Moses (1942) was published when "racial segregation and white supremacy were," in Thadious Davis's words, "not merely ingrained patterns of Southern thought, but accepted civil institutions as well" (1983, p. 23). William Faulkner experienced the Southern racial conflict very intensely, but he could, especially in the fiction of his major phase, distance himself from society and dramatize its racial contradictions. However, he felt compelled, later in his career, to relinquish this distance and make statements on the conflict both in his fiction and non-fiction. Go Down, Moses, one might observe, signals the beginning of the shift to making statements on social issues. ${ }^{1}$ Yet it still has the strengths of his major writing phase, which, to use Richard Gray's words, lay in 
"the transformation of historical conflict into the processes, the enacted debates of fiction" (1994, p. 276).

The text's tendency to comment directly on race relations can be seen in many instances. Ike McCaslin's specification of "a thousand or two thousand years" as the time needed for a real change in race relations in America is one memorable instance (Faulkner, 1942, p. 346). Indeed, it echoes and exaggerates Faulkner's above mentioned reference to three hundred years. In this article, I am more interested in the less direct engagement with the race issue, which, as I have alluded earlier, demonstrates the sophistication of this text's dramatization of change in relation to the race issue in the American South. The status of Go Down, Moses as a novel has been questioned by critics, and Faulkner himself described the book, at different times, as a collection of short stories and as a novel. ${ }^{2}$ Indeed, the book's tensions and discontinuities are functional within the context of Faulkner's literary response to race relations. Susan Donaldson observes that these tensions and discontinuities achieve a "small measure of victory" in the literary effort to resist the monologic discourse of the McCaslin ledgers with the "unending nature of" the literary struggle "to revise and transform" the ugly facts of those ledgers (1992, p. 147). John Carlos Rowe proposes "a more radical disunity in this collection that focuses on Faulkner's ultimate inability to grant his African American characters the independent voices he knows they must have in a truly New South" (1997, p. 231).

I would like to expand this "small measure of victory" to include even the attempts of the scribers of the ledgers themselves at challenging and subverting the codes of the race ideology in the South. I argue that the conflict between subverting the racial codes and the counter attempts to maintain these codes creates a circular movement which gives a false impression of a stable society with fixed codes. The text, however, suggests a more subtle forward movement propelled by the aggregate of the subversive attacks which are directed at the southern racial codes. I find in this forward movement a real measure of victory, far more effective than the direct statements on the race issue.

The earliest attempt at challenging slavery in Go Down, Moses can be found in the ledgers, which are one of Go Down, Moses's several texts. It is also in the ledgers that we read slaveholders' counter attempts to question the agency which this challenging attempt suggests. Eunice's drowning of herself in an act of protest and the incredulous and undermining response of the McCaslin brothers to this act set a model for a long series of acts of protests and questioning responses to these acts. Our reading of the ledgers is actually a reading of Ike McCaslin's reading of these ledgers. It is true that we have access to some of the original text as it written by Ike's father and uncle, but it is Ike who chooses what is to be read.

Section Four of "The Bear" describes how Ike, the last white male descendent of the McCaslin family, comes to know about the secrets of his family's past when he reads the plantation ledgers. Ike's reading takes an investigative form, which is reminiscent of Nathaniel Hawthorne finding the mysterious scarlet letter $A$ in Salem's custom house. ${ }^{3}$ He secretly takes the key to the commissary after midnight, while his cousin is asleep, and opens the ledgers, "with the commissary door shut and locked behind him and the forgotten lantern stinking anew and rank with icy air" (Faulkner, 1942, pp. 257-8). Reading the ledgers at the age of sixteen is by no means Ike's first acquaintance with the contents of the ledgers as the reminder, "he knew what he was going to find before he found it," is repeated in different variations. The engagement with the ledgers becomes so strong for Ike to the extent that he seems to see the "injustice" which is recorded there enacted in front of him. Absorbed with what his father and uncle wrote about their father's slave Eunice, who had drowned herself back in 1833, seems to enable Ike to see Eunice "actually walking into the icy creek on that Christmas day six months before her daughter's and her lover's ... child was born" (Faulkner, 1942, p. 260).

It is very important to note that the ledgers tell only a minor part of the family's history. Ike concentrates on what his father and his uncle wrote, leaving the more disturbing writings of old Carothers unread. Examining the available part of the ledgers, we find that Ike's father questions Eunice's agency to act subversively by taking her own life to put an end to her exploitation by her master, and express her horror at his immoral act of impregnating "his daughter." The ledgers entries of the McCaslin brothers regarding Eunice read as follows, with Ike's father writing first:

Eunice Bought by Father in New Orleans 1807 \$650. dollars. Married to Thucydus 1809 Drownd in Crick Christmas Day 1832

and then the other hand...his uncle's...:

June 21th 1833 Drownd herself

and the first:

23 Jun 1833 Who in hell ever heard of a niger drownding him self 
and the second...:

Aug 13th 1833 Drownd herself. (Faulkner, 1942, pp. 256-7)

The way the brothers deal with Eunice's drowning shows that they treat the fact of her death as a financial loss of $\$ 650$ dollars. Their written communications over long intervals indicate that they did not regard the incident as important enough to have a conversation about it. Thus, the suicide of Eunice remains an unhealed wound.

Even though the two brothers have a chance to redeem their father's incest by acknowledging Tomey's Turl as their brother, they fail in doing so. All they achieve is agreeing to fulfil their father's will to pay $\$ 1000$ to Tomey's Turl, which does not go beyond what old Carothers has already done. Ike concludes that his grandfather's will "was cheaper than saying My son to a nigger." The only redeeming possibility for old Carothors that Ike can speculate about is love: "there must have been love...Some sort of love. Even what he would have called love: not just an afternoon's or a night's spittoon" (Faulkner, 1942, p. 295). This reference to love remains, of course, a speculation on the part of Ike. If we consider Ike's poor knowledge of love especially across the colour line, as the unnamed mullata in "Delta Autumn" will demonstrate, then there is a good chance to suggest that Ike is doing what Jan Lewis cautions against which is "translat[ing] sex as love" (2003, p. 115). ${ }^{4}$

The brothers' failure to acknowledge Tomey's Turl is quite disappointing, but their slaveholding style is more of an anomaly and there are good possibilities to read this style as subversive of slavery and its codes. This is seen, for example, in the way the two brothers exchange their accommodation with that of their slaves. Within the context of slavery, this change is quite substantial, and the brothers are actually mocking their father and other slaveholders. We are told that: "the two brothers who as soon as their father was buried moved out of the tremendously-conceived, the almost barn-like edifice ... into a one-room log cabin $\ldots$ and domiciled all the slaves in the big house" (Faulkner, 1942, p. 251). Slaves, who are usually not allowed to get into this house except from the back door, are subversively made to inhabit the place of their masters. The speed and the urgency in which the brothers accomplish this change indicate that they have been troubled by the fact that the house in which they have lived was built by slave labour. Moving slaves into the house they built and building their own room in the form of slaves' cabin, the brothers hope, are possible ways to ameliorate their father's injustice to his slaves. Although it is very difficult to be categorical about the brothers' motive, this is strongly suggested by their insistence on doing without slaves' labour as much as they can.

The McCaslin house is an example of several famous Yoknapatawpha houses which are built by Southern family founders with the intention of being made sites of continuity, bequeathed by fathers to sons, to ironically become sites of subversion and social change. In the Snopes trilogy Major de Spain's mansion becomes a site of economic transformation when it is usurped by Flem Snopes. It is obvious that old Carothers conceived of his house, especially its huge and impressive size, to be, like that of Pettibone in Tidewater, the site of a dynasty. The McCaslin house, however, becomes a site of subversion in race relations as old Carothers's sons refuse to occupy it, not to say complete its building according to their father's original design. The use of the description "abortive edifice" becomes more appropriate to the subversive uses its various occupants put it to than to the actual aborted building of the house. Actually, the house will be completed later with money from the dowry of Ike's mother.

The way the house is left uncompleted with some of its windows merely boarded up with odds and ends of plank or with animal hides nailed over the empty frames demonstrates not only interruption and contradiction between father and sons, but also the sons' contempt for the father's "design," to use Thomas Sutpen's term. ${ }^{5}$ This contempt is completed by moving the slaves to live in the house itself. Owen Robinson, who compares the changes that take place in the McCaslin and the De Spain houses, concludes that there is a difference between the two cases: "Flem, though a Yoknapatawphan by birth and heritage, is a class outsider motivated by profit, and apparently without thought for what he is usurping, proceeds to change the face of the county. The McCaslin twins, on the other hand, do not infiltrate and take over, but rather dismantle from within" (2006, p. 151). The brothers' attempt to atone for the past by freeing themselves from dependence on slave labour remains incomplete, however, for they resort to slave labour when they cannot do the work on their own. Furthermore, this subversion in the McCaslin house proves to be a temporary one and it becomes possible to talk about a partial subversion of their progressive step. When Buddy McCaslin is trapped into marriage, his wife Sophonsiba Beauchamp restores, at least partially, the old order by moving along with her husband to the big house, returning in the process the McCaslin slaves to their old cabins. Uncle Buck, however, remains in his cabin, living next to the slaves. ${ }^{6}$

The way the McCaslin brothers confirm their control over their slaves by parading them and then herding them "into the tremendous abortive edifice" is another subversive instance of their slaveholding style. Ike remembers 
that when he was a boy there was a sort of folk-tale: "of the countryside all night long full of skulking McCaslin slaves dodging the moonlit roads and the Patrol-riders to visit other plantations, ..." (Faulkner, 1942, p. 252). This control is usually enforced by complex surveillance systems and cooperation among slaveholders and it is enacted in extreme cases, as we read in Beloved for example, in iron chains (Morrison, 1987, pp. 82-3). The brothers are mocking this control by using a home wrought nail for a lock to the front door to the house, which had no hinged back door at all. No doubt, this treatment is regarded as dangerous by other slaveholders. This is because their plantations are visited at night by the McCaslin slaves, who disseminate new ideas of the relationship between slaves and their masters. Neighbouring planters' response to the McCaslin brothers can be seen in the way Hubert Beauchamp, the owner of Warwick plantation, replies to the suggestion that he buy Tomey's Turl to stop him from running away. We are told by the narrator in the first story "Was" that "Mr Hubert said he not only wouldn't buy Tomey's Turl, he wouldn't have that damn white half-McCaslin on his place even as a free gift, not even if Uncle Buck and Uncle Buddy were to pay board and keep for him" (Faulkner, 1942, p. $5)$.

The brothers' response to Tomey's Turl's repeated running away to see his girl at Hubert Beauchamp's plantation, which is about twice a year, is a third instance of the brothers' subversive slaveholding style. This act, which is usually regarded among slaves' worst offences, is dealt with by returning Tomey's Turl back without punishing him. This, of course, encourages him to repeat his act. Thadious Davis reads this act as a challenge to slaveholders but only within the game context $(1996$, p. 135). I think this challenge is possible only because of the two brothers' subversive slaveholding style, which interestingly coincides with both Hubert Beauchamp and his sister's desire to fix Sophonsiba's marriage to one of the McCaslin brothers. It is actually possible to read the response of the Beauchamps to Tomey's Turl in this way, too. While strict, if not complete, restrictions would be imposed on communications between a male slave of around twenty one and a young white woman, Hubert allows his single sister to conspire with Tomey's Turl to trap one of the McCaslin twins into marriage.

When the ownership of the McCaslin plantation in transferred to Ike, the hope for a significant redemptive and subversive act to be undertaken by Ike becomes quite strong. This is because of the expectations which Ike creates in the reader while reading and responding to the racial heritage of his family in the ledgers. The ledgers, however, are not Ike's only source of knowledge about the past of his family. He has other sources, such as the men whom he accompanies to the woods and listens to their tales. ${ }^{7}$ Sam Fathers emerges as the strongest influence on Ike as seen in the way Sam's tutelage influences the way Ike reads the ledgers, takes his decision to repudiate his inheritance and debates his decision with his cousin. Like the ledgers, Sam is able to bring the past into life. We are told that when young Ike listened to Sam's tales about the past, "those old times would cease to be old times and would become a part of the boy's present, ..." (Faulkner, 1942, p. 165). In addition to hunting, Sam teaches Ike a great deal about the history of the South, which enables Ike to look at the past of his family from the viewpoint of oppressed people like Sam. Actually Ike combines the information he receives from Sam with what he finds in the ledgers, which tell the story cryptically from the viewpoint of the victimizers, slaveholders.

Ike's debate with his cousin McCaslin Edmonds can be read as taking place inside Ike with two voices, the voice of the other being represented by Sam and the voice of the fathers being represented by his cousin, competing to make Ike take the decision each of them wants him to take. The cousins' debate reveals that Edmonds regards old Carothers as someone who saw an opportunity and took it. He confirms that old Carothers "bought the land, took the land, got the land no matter how, held it to bequeath, no matter how... translated it into something to bequeath to his children" (Faulkner, 1942, p. 246). As if the repetition of "the land" with different verbs of possession, "bought," "took," and "got" is not enough to indicate Edmonds's indifference to the way the land was obtained, he is keen to add "no matter how." Guilt for the way the land was obtained or the slaves were treated is dismissed completely by him. Ike, by contrast, not only defends black people's vices, but also celebrates their virtues: "[t]hey are better than we are. Stronger than we are. Their vices are vices aped from white men or that white men and bondage have taught them ..." (Faulkner, 1942, p. 282).

Ike's decision to repudiate his "right" to the land can be considered, in a way, a major step towards a real change in race relations and a positive response to the terrible legacy of the past. Unfortunately, the way Ike performs this repudiation renders it a meaningless step, meant to appease his own guilt rather than create a badly needed change in the family. Instead of giving the land to the black people or even sharing it with them because it has been farmed by their labour for generations, Ike gives the plantation to the Edmondses. The Edmondses are tougher than his father and uncle in dealing with black people and they do not cherish Ike's ideas regarding land ownership. Ultimately, Ike's act, though not meant to be so, amounts to subverting his father and his uncle's "good" acts, rather than old Carothers's ruthlessness. Both Zack and Roth Edmonds reproduce old Carothers's 
relationship to black women, though under different circumstances as slavery is abolished in their times.

Echoing his father's and uncle's dependence on slave labour to raise the heavy logs while building their cabin, Ike, though tellingly takes the Nazarene as his example in choosing carpentry as a profession, still depends on black labour as he takes the allowance Roth specifies to him from the plantation money.

In "Delta Autumn," Ike, as an old man, meets an unnamed "mulatta," who turns out to be related to him. She is the granddaughter of "Tennie's Jim," who is the son of Tomey's Turl, Ike's unacknowledged uncle. This woman evokes two responses in Ike. On the one hand, her relationship to Roth Edmonds, the current owner of the McCaslin plantation, is a residue of slavery in the sense that it echoes old Carothers's relationship to his female slaves. Indeed, Roth's refusal to acknowledge his relationship to this woman and the child he fathers on her is even stronger than that of old Carothers's. Roth is careful not to even mention his name in relation to her when he sends money to her bank in Vicksburg. This enlists the same old response from Ike: guilt and willingness to pay money in atonement. On the other hand, this woman's behaviour is quite subversive to Ike's expectations of black women, or black people in general. Indeed, he regards her as more subversive than Fonsiba, Lucas's sister, who shocks him by preferring poverty with freedom in Arkansas to life on the plantation, the site of her ancestors' enslavement. This unnamed woman's encounter with Ike in the tent is to a great extent similar to Lucas's encounter with Zack Edmonds in the latter's bedroom. Her own achievements, which render her empowered and hence subversive, enlists a different response from Ike. He addresses her: "[y]ou sound like you have been to college even. You sound almost like a Northerner even, not like the draggle-tailed women of these Delta-peckerwoods" (Faulkner, 1942, p. 345). She shocks him even further when she rightly claims that the most important decision he took in his life led to one thing only: spoiling Roth Edmonds.

Ike makes a very negative exit when he suggests that the South has no place for empowered "black" women like this relative of his: "Go back North. Marry: a man in your own race. That's the only salvation for you-for a while yet, maybe a long while yet" (Faulkner, 1942, p. 348). In this way, Ike regresses back as he preaches segregation. He specifies in his thoughts the "long while" which is needed to make change in race relations as follows: "Maybe in a thousand or two thousand years in America." (Faulkner, 1942, p. 346). When it comes to change, Ike is a gradualist at best. His opposition to the possibility of marriage between this woman and the white father of her child subverts all that he has done. Her concluding words remind him of what he once believed to be black virtues: "have you lived so long and forgotten so much that you do not remember anything you ever knew or felt or even heard about love?" (Faulkner, 1942, p. 348). This expression is unfamiliar and quite subversive to Ike because it, according to Deborah McDowell, "lies outside the ideological scripts of history." McDowell adds that this woman's "relationship to Roth conforms to the sexual and racial codes of the antebellum economy that made black women's bodies readily available for white-male consumption, but she views that relationship in terms that this code can neither capture nor control" $(2010$, p. 106). Ike realizes that the old way of paying money is not enough. His modest attempt to acknowledge this woman's demands for love and recognition by giving her his horn is nothing more than acknowledging his own defeat by the power of the claims she makes and the eloquence in which she puts them.

Describing the first stage of the Afro-American response to Faulkner, Craig Werner, speaks about "a fairly clear consensus that while Faulkner was a good observer, he consistently interpreted Afro-American behaviour in static rather than kinetic terms, substituting 'endurance' for 'ascent' and 'immersion'" (1987, p. 37). This reference to "endurance" in relation to Faulkner's black characters is also confirmed by Edouard Glissant. He observes that these black characters "do not speak of the past: they suffer it and perpetuate it through suffering. By carrying on this 'role,' they re-create the past. With rare exceptions, they cannot contaminate anyone or make any decisions for change." The significant exception he mentions is Clytie Sutpen, "who at the end of Absalom, Absalom! sets fire to the place and, through this apocalyptic destruction, ordains the end of the story" (1999, pp. 62-3). In Go Down, Moses, black characters do not set fire to the McCaslin house but they, as we have already seen, live in it subversively for a while. ${ }^{8}$ Furthermore, a black character will enter the house asking for justice and another will break into the commissary, the place that has sucked the fruit of their labour for generations, at the risk of their own lives.

In the second story, "The Fire and the Hearth," Lucas Beauchamp regards himself as the oldest living McCaslin, though he is not acknowledged as such. Lucas is the son of Tomey's Turl, who was the outcome of old Carothers's incestuous affair with his slave daughter Tomsina. As Ike steals into the commissary after midnight to encounter the past of his family by reading the plantation ledgers, Lucas encounters something of that past as he goes after midnight to dig a new place for his still. The past appears to Lucas in the form of a gold coin, which drives him into a frenzy. This excitement exposes, as the narrative tries to capture Lucas's thoughts, the way he regards his past and his white ancestors in particular. It is important to stress that unlike Ike, Lucas, when 
he goes out at night, is not driven by any desire to encounter that past. Later in the story, however, Lucas becomes obsessed with digging the earth in hope of finding some buried gold, which he, after all, appreciates in its monetary and hereditary values, preferring the monetary one, of course. Lucas encounters the past as he is dealing with a pressing concern from the present, which is eliminating his rival in moonshining, George Wilkins, who also wants to get married to Lucas's daughter Nat. Lucas's attitude to the past is anything but usual. We do not know how much he knows of the atrocities that were committed against his black ancestors, but we can deduce that he knows a lot. Indeed, he knows that he is related to the family's founder through a relationship between old Carothers and his grandmother, which produced his father. Of course, this relationship was not acknowledged formally by old Carothers or his sons Uncle Buck and Uncle Buddy. We are not sure that Lucas is aware that this relationship led also to the suicide of his grandmother Eunice, but we know that his brother James and his sister Fonsiba are aware of that.

Lucas's decision to stay in the family, and even to ask for his share of old Carothers' will is a pragmatic move. This money is after all what old Carothers decided to pay for a terrible crime he had committed against his own "daughter." Lucas does not seem to bother about the way the money became his. Furthermore, he is not only proud of his ties to the family founder, but also finds in that one more reason for feeling superior to George Wilkins, the black man who is not related to the McCaslins. More significantly, Lucas feels superior even to the current white owners of the plantation who are related to old Carothers on the distaff side. Lucas entertains the idea of partnering Wilkins in business, moonshining, but as soon as he finds his ancestors' money and his pride in his relationship to old Carothers is revived, he changes his mind.

He, Lucas Beauchamp, the oldest living McCaslin descendent still living on the hereditary land, who actually remembered old Buck and Buddy in the living flesh, older than Zack Edmonds even if Zack were still alive, almost as old as old Isaac ...- he, to share one jot, one penny of the money which old Buck and Buddy had buried almost a hundred years ago, with an interloper without forbears and sprung from nowhere and whose very name was unknown in the country twenty-five years ago-a jimber-jawed clown who could not even learn how to make whisky, ... Never. (Faulkner, 1942, pp. 39-40)

As we see, Lucas's feelings of superiority to Wilkins are not completely racial: Lucas is proud of his efficiency in farming and making whisky. Yet, when Lucas describes Wilkins as "a jimber-jawed clown," he uses the same racist remarks that will be used about Wilkins by a judge in Jefferson's court. Also when Lucas rehearses the names of his ancestors in this passage, he drops the name of his mulatto father Tomey's Turl, which shows that he is proud of his white ancestors only.

The way Lucas stays on the McCaslin plantation raises several questions. Lucas's relationship to "his" farm in the McCaslin plantation is described in ambiguous terms. It is quite subversive not only of the codes of racial relationships between whites and blacks, but also to economic arrangements between landlords and tenants. Lucas's love for money, especially "hereditary" money and "hereditary" land, makes the claim that Lucas does not want to own "his" field difficult to swallow. Lucas enjoys "freedom" on "his" farm not merely because he is related to the McCaslins - a relationship, which is not acknowledged formally in the first place. How can Lucas, then, afford to ignore his landlord? The answer is, partially, that he is not a full sharecropper as he does not need to renew his contract every year and face the possibility of having to leave his farm to another one. Furthermore, Lucas uses extreme measures of discretion so that he does not fall in debt to the commissary. In addition to this, he supplements his income with moonshining.

Despite all of this, Lucas's arrogance in the way he deals with Roth is the opposite of why black tenants were preferred by landlords to their white counterparts. Black farmers' racial subordination made them more compliant to unfavourable lease arrangements and to the intimidation used by landowners to prevent croppers from moving to more favourable conditions (Kirby, 1987, p. 237). Lucas's relationship to the land remains, I think, quite anomalous and subversive. But as is the case with many of the subversive racial relationships in this book, we see how Lucas's relationship to the land develops when his grandson Butch breaks into the commissary. Roth drives Butch out of the plantation altogether, "[s]old him in Egypt," Butch's grandmother explains to the county attorney Gavin Stevens, and eventually restores racial relations in the McCaslin plantation to similar racial relations in the South.

Lucas's encounter with Zack in his bedroom is subversive of almost all the relevant Southern racial codes. First of all he subverts the very motif of entering from the back door. Lucas changes the meaning of the entrance from being a passage into humiliation and inferiority to one of bidding for equality, even by risking being lynched at the hands of white mobs. Furthermore, Lucas actually achieves that equality as Zack is forced to concede it by accepting Lucas's offer of a duel, which means a fair test of strength between "equal" opponents. The site of the 
duel is even more important than the back door. Entering into the white man's bedroom and fighting him on his own bed, which are known sites of white men's exploitation of Lucas's grandmother and black women in general and very probably his wife, Lucas reverses the meaning of these sites and the terms of his relationship to Zack. The description of the duel presents Zack in feminine terms, especially in the way he is pinned down by Lucas's controlling "embrace." By contrast, Lucas's masculinity is emphasized as he holds the phallic pistol in his hand.

Zack's act in keeping Lucas's wife is, in a way, a subversion of the emancipation of black people as his act echoes that of old Carothers with his female slaves. We are not sure about a sexual relationship between Zack and Molly, but Lucas thinks that it might be the case. " "How to God," he exclaims, "can a black man ask a white man to please not lay down with his black wife? And even if he could ask it, how to God can the white man promise he wont?" (Faulkner, 1942, p. 58) ${ }^{10}$ He even refers to this possibility in the duel: "You thought that, because I am a nigger I wouldn't even mind" (Faulkner, 1942, p. 52). This difficult position for black men and women against white men makes Lucas's act even more subversive. Here, Lucas is consciously subverting racial codes or white people's expectation of how black people should behave: that is not to retaliate against aggression. Lucas not only demonstrates that he has pride and that Zack's act has challenged his pride, but also goes on to remind Zack of the point which he believes himself to be superior to Zack in. He declares that Zack is related to old Carothers on the distaff side, while he is related to him through the male line. Lucas's reference to a white woman in this context of male rivalry over a black woman is very daring.

As Lucas cannot enter the house subversively from the front door after this encounter, he continues to act subversively by abstaining from entering from the back door, which is enough to reduce Zack, and his son Roth later on, to impotent rage. Since his childhood Roth remarks how "Lucas always referred to his father as $\mathrm{Mr}$ Edmonds, never as Mister Zack, as the other negroes did, and how with a cold and deliberate calculation he evaded having to address the white man by any name whatever when speaking to him" (Faulkner, 1942, p. 102). Roth witnesses further how Lucas avoids to use the word "sir" in the court in Jefferson, which angers the white clerk, who exclaims: "[w]hy, the uppity_" (Faulkner, 1942, p. 125). As we see, Lucas's way of self-assertion is often negative. He does not give whites the servility they require from black people, but, with the exception of his encounter with Zack, he cannot afford to require that they deal with him as an equal man.

In Intruder in the Dust, Lucas goes a step further. He demands that Charles Mallison respect him when he refuses to take the money which Charles sends in return for Lucas's help in saving Charles from drowning and cold. Lucas succeeds there, but that happens only after Charles himself undergoes a process of maturation that enables him to see Lucas as an equal man, worthy of respect. Charles is the second white boy to stay at Lucas's place. Despite his short stay, he achieves maturity through the interaction with Lucas, which follows this stay. By contrast Roth Edmonds, who is actually brought up by Lucas and his wife Molly and who lives with their son Henry as a brother, fails to gain this maturity. He rejects his "brother" as soon as he is exposed to the racial codes of the white society, which he learns from school.

If Lucas proves his physical strength and masculinity by defeating his white cousin Zack, and his son Roth by extension, then Lucas's comic engagement with the white divining machine salesman from Memphis is a battle of wits. Echoing Flem Snopes's legendary act of selling the Old Frenchman place, Lucas manages to get a $\$ 300$ machine for part of the money which he has actually buried in separate places and later shared with the white salesman. He even manages to lend the machine to its salesman for \$25 a night. The way the salesman is left searching and digging like Henry Armstid in The Hamlet shows the similarity between Lucas and Flem, but the way Lucas comes to the commissary to brag about his success without Roth's help marks the difference between Lucas and Flem. Lucas cannot resist expressing his pleasure at defeating his white opponent, whereas Flem's response to winning, which becomes almost certain and unsurprising, remains unknown. Lucas's winning is undermined further as he becomes addicted to the machine, to the extent that his relationship to his wife is seriously threatened and they actually go to court to be divorced, only to change their minds in the last minutes. Lucas's surrender of the machine at the end of the story subverts his success.

Richard Gray explains the contradictions in presenting Lucas by the inclusion of some comic short stories, which present Lucas as a stereotypical character, in the serious discussion of race relations in Go Down, Moses (1994, pp. 273; 278). These contradictions serve to subvert the more positive presentation of Lucas, which might also be seen, for example, in the way Lucas is recalling his brave encounter with Zack. We are told that a change takes place in his character when he meets with Zack's son: "[w]ithout changing the inflection of his voice and apparently without effort or even design Lucas became not Negro but nigger, ... enveloping himself in an aura of timeless and stupid impassivity like a smell" (Faulkner, 1942, p. 59). The mere joining of the positive image of Lucas defeating Zack with the negative image presented in this unexplained change compromises the first positive image of Lucas. Lucas's positive qualities are undermined even further in the way he deals with the 
legal system after his still and that of Wilkins are discovered by the police. Lucas depends on Roth to pay his bail and save him from imprisonment, which ultimately renders Lucas as a rebellious child rather than the subversive man he has been. ${ }^{11}$

In "The Fire and the Hearth," Molly Beauchamp, who is kept by Zack Edmonds in his house against the wish of her husband, is not presented as thinking of herself as a victim. Unlike her husband, she does not disrupt the race relations inside the family in any significant way. On the contrary, her endurance, to use Glissant's words, perpetuates the past. Like Dilsey Gibson, Molly plays the role of the mammy, who according to Diane Roberts, "is not a subversion of the symbolic order that places white over black in Faulkner's South" (1994, p. 57). ${ }^{12}$ This presentation emphasizes the nursing aspect of Molly's character at the expense of her sexuality, which is associated with young black women. While we constantly see her with children, we never see her in the company of Zack. Furthermore, the description of her body, which is rendered in almost the same words that are used in describing Granny Rosa Millard in The Unvanquished, almost eliminates all references to her sexuality.

In the last story, "Go Down, Moses," Molly does not act subversively, but the inability of Gavin Stevens, the county attorney, and other Southern whites, like the editor of the county newspaper, to understand her grief at the death of her grandson renders her behaviour subversive. When the name of Butch is mentioned, Stevens remembers him and his comments shift towards generalizing about blacks instead of treating Butch as an individual. He remembers him as "a youth not yet twenty one, with something in him from the father who begot and deserted him and who was now in the State Penitentiary for manslaughter-some seed not only violent but dangerous and bad" (Faulkner, 1942, p. 356). Stevens's failure to deal with blacks as individuals is made even clearer when he comments on his realization that Molly and Hamp Worsham are siblings: "[t]hey were like that. You could know two of them for years; they might even have worked for you for years, bearing different names. Then suddenly you learn by pure chance they are brothers or sisters" (Faulkner, 1942, p. 356). With such an attitude towards black people, Stevens, no wonder, regards Molly's request to defend her grandson's case a subversive behaviour on the part of a black woman.

In Intruder in the Dust, Stevens is shocked by the proposal of Molly's husband to "hire" him (Faulkner, 1948, p. 59). When Lucas asks for a receipt for the money he pays in return for Stevens's service, Stevens is completely bewildered by this move. Like Ike McCaslin, who exits in "Delta Autumn" in a disappointing way, Stevens concludes "Go Down, Moses" incapable of appreciating black people's emotions and Molly's grief. He interprets Molly's desire to bring the body of her executed grandson in a proper manner as follows: "[s] he just wanted him home, but she wanted him to come home right. She wanted that casket and those flowers and the hearse and she wanted to ride through town behind it in a car" (Faulkner, 1942, p. 367). After more than a century, Stevens's response echoes Uncle Buck's incredulous response to Eunice's suicide in the way both of them trivialize African Americans' grief.

The news of Butch's execution reads as the following in the press association flimsy: "Mississippi negro, on eve of execution for murder of Chicago policeman, exposes alias by completing census questionnaire. Samuel Worsham Beauchamp_-" (Faulkner, 1942, p. 358). This reads very much like the ledger entry which documents Eunice's suicide. Molly wants Butch's entire story in the paper because the full story will provide an account of Butch as an individual. It will also explain the details of why he has killed the policeman. This simple wish on the part of Molly is likewise regarded as quite subversive to the expectations of the paper editor, who, like Gavin Stevens, assumes that "the darkies" do not read newspapers. Indeed, Molly and Butch remain disadvantaged even if the whole story comes out in the paper for Molly cannot be sure that the editor will be fair in presenting the story. Butch's broken mouth is an important detail, which serves to emphasise his silence. ${ }^{13}$

If Butch's story demonstrates the unwillingness to publish black people's full stories, then the story of Rider, the main character of the third section in the book, "Pantaloon in Black," demonstrates the process of subverting "truth." The first part of the story has its strength especially in the way it acknowledges the otherness of Rider while capturing the intensity of his grief at the occasion of his wife's death. The moment Rider enters his house and finds himself faced with loneliness is particularly powerful:

But when he put his hand on the gate it seemed to him suddenly that there was nothing beyond it. The house had never been his anyway, but now even the new planks and sills and shingles, the hearth and stove and bed, were all a part of the memory of somebody else, so that he stopped in the half-open gate and said aloud, as though he had gone to sleep in one place and then waked suddenly to find himself in another: "Whut's A doin hyar?" (Faulkner, 1942, p. 134-5).

Glissant observes that Faulkner rarely uses "the subjective narrative mode" and almost never uses the interior monologue in his writings about black people. ${ }^{14}$ Instead of weaving into Rider's consciousness, his grief is 
conveyed in the way he responds to the physical objects of the external world as seen for the first time in isolation from his lost love, which makes them all the more associated with his loss. Indeed, the text's description of Rider's response to the absence of his wife Mannie highlights her agency especially in the way she has changed Rider's behaviour and his concept of himself. Benjamin Ogden explains that Rider's grief "is a product not only of a romantic love that white America at the time may not have imagined black men to be capable of, but of an awareness of his place within both a cosmic and secular order that one could argue is integral for social change. (2008, p. 395). Rider and Mannie present a positive image of a family whose success is based on romantic love and hard work. In this family Faulkner presents an alternative to the troubled McCaslin family and its painful heritage of exploitation and denial.

According to Walter Taylor, Rider “represents Faulkner's only attempt at anything approaching a genuine African hero: the dominating male who is the reverse image of the clown of plantation propaganda" (1972, p. 434). The power of Rider's presentation can be seen in the way the first positive presentation is subverted by the deputy's version of the same story, which he tells to his disinterested wife in their kitchen. Like Gavin Stevens and the editor of the county paper, the deputy not only fails to understand Rider's grief, but also the emotions of black people in general: "[b]ecause they aint human. ... when it comes to the normal human feelings and sentiments of human beings, they might as well be a damn herd of wild buffaloes" (Faulkner, 1942, pp. 149-50). The way Faulkner places the two versions of Rider's story together demonstrates the way Southern whites' readymade concepts about black people make them interpret black people' normal behavior as subversive and even threatening. The deputy's version consists of conscious imposition of a readymade stereotype on Rider. At certain moments, however, it shows real confusion on his part. This version of the story is an example of the way the subversion of truth blinds the prejudiced author of the biased account and contributes to perpetuating racial segregation.

\section{Conclusion}

To return to Glissant's claim that Faulkner's black characters do not make decisions for social change, I would like to confirm that Go Down, Moses abounds with such decisions for change. Moreover, these decisions are made by both black and white characters. If these decisions seem to be overshadowed, then this can be explained by the strong tendency of the racial codes to reproduce themselves because they are deeply entrenched in the Southern white society. The way Roth Edmonds, the last white member of both the McCaslin and the Edmonds families, repeats old Carothers's exploitation of black women suggests a vicious circle which seems to block the possibility of social change. The text's tensions and discontinuities cannot be overshadowed, however, and they are a function of the continuous conflict between the attempts at making decisions for change by challenging the racial codes and the counter attempts to reinstate these codes.

Even though Go Down, Moses ends, as Minrose Gwin observes, "with denial by white men of the wounds of racial trauma" (2004, p. 27), the book achieves a "measure of victory," in the way its narrative techniques acknowledge and respect the otherness of black people, and, more importantly, in the way it maintains the determination to subvert the codes of the Southern racial ideology by both white and black characters. Unfortunately, Rider's and Butch's acts of protest and Eunice's suicide take a violent form. This does diminish their power, however. James and Fonsiba Beauchamp's departure, and Lucas's determination to preserve his pride finally culminate in the eloquent and powerful demands for love and recognition, which are made by their unnamed descendant. Go Down, Moses's dramatization of black people's growing empowerment leaves little doubt that the way they will put their demand for love and recognition is going to be more forceful. In Go Down, Moses, racial codes prove to be so persistent and resistant to change, but so is the resistance to oppression and the determination to change these codes. In light of the growing empowerment of black characters, this continuous conflict between subverting and maintaining racial codes leaves no doubt that these codes are being weakened. Dramatizing social change in the form of textual tensions and discontinuities and weakening racial codes is a mark of the sophistication of the text's indirect engagement with social change.

\section{References}

Davis, A. (1983). Women, Race and Class. New York, NY: Random House.

Davis, T. M. (1983). Faulkner's Negro: Art and the Southern Context. Baton Rouge: Louisiana State University Press.

Davis, T. M. (1996). The Game of Courts: Go Down, Moses, Arbitrary Legalities, and Compensatory Boundaries. In Wagner-Martin, L. (Ed.), New Essays on Go Down Moses. (pp. 129-54). Cambridge: Cambridge University Press. http://dx.doi.org/10.1017/CBO9780511624568.007 
Donaldson, S. V. (1992). Contending Narratives: Go Down, Moses and the Short Story Cycle. In Harington, E., \& Abadie, A. J. (Eds.), Faulkner and the Short Story: Faulkner and Yoknapatawpha 1990 (pp. 128-48). Jackson: University Press of Mississippi.

Faulkner, W. (1942). Go Down, Moses. New York, NY: The Modern Library.

Faulkner, W. (1948). Intruder in the Dust. London: Vintage.

Faulkner, W. (1959). Faulkner in the University. F. G. Gwynn, \& J. L. Blotner (Eds.). Charlottesville: University Press of Virginia.

Faulkner, W. (1967). Essays, Speeches and Public Letters. J. B. Meriwether (Ed.). London: Chatto \& Windus.

Glissant, E. (1999). Faulkner, Mississippi. (B. Lewis, \& T. C. Spear, Trans.). Chicago: The University of Chicago Press. (Original work published in 1996).

Godden, R., \& Polk, N. (2002). Reading the Ledgers. The Mississippi Quarterly, 55(3), 301-59.

Gray, R. J. (1994). The Life of William Faulkner: a Critical Biography. Oxford: Blackwell Publishers Ltd.

Gwin, M. C. (2004). Racial Wounding and the Aesthetics of the Middle Voice in Absalom, Absalom! and Go Down, Moses. The Faulkner Journal, 20(1-2), 21-33.

Hawthorne, N. (1850). The Scarlet Letter. Ware, Hertfordshire: Wordsworth Editions Limited.

Hurston, Z. N. (1937). Their Eyes Were Watching God. London: Virago.

Kirby, J. T. (1987). Rural Worlds Lost: The American South 1920-1960. Baton Rouge: Louisiana State University Press.

Ladd, B. (2007). Race as Fact and Fiction in William Faulkner. In Moreland, R. C. (Ed.), A Companion to William Faulkner (pp. 133-47). Malden, MA: Blackwell Publishing LTD. http://dx.doi.org/10.1002/9780470996881.ch9

Lewis, J. (2003). Commentary. In Jordan, W. (Ed.), Slavery and the American South (pp. 108-16). Oxford: Univesity Press of Mississippi.

McDowell, D. E. (2010). "Must have been Love:" Sexualities’ Attachments in Faulkner. In Trefzer, A., \& Abadie, A. J. (Eds.), Faulkner's Sexualities: Faulkenr and Yoknapatawpha 2007 (pp. 94-114). Jackson: University Press of Mississippi.

Meriwether, J. B., \& Millgate, M. (1968). Lion in the Garden: Interviews with William Faulkner 1926-1962. New York, NY: Random House.

Morrison, T. (1987). Beloved. London: Vintage.

Ogden, B. H. (2008). Rethinking Rider's Love: The less-Romantic Logic of Property and Space in "Pantaloon in Black." Mississippi Quarterly, 61(3), 379-96.

Roberts, D. (1994). Faulkner and Southern Womanhood. Athens: The University of Georgia Press.

Robinson, O. (2006). Creating Yoknapatawpha: Readers and Writers in Faulkner's Fiction. New York, NY: Routledge.

Rowe, J. C. (1997). At Emerson's Tomb: The Politics of Classic American Literature. New York, NY: Columbia University Press.

Taylor, W. (1972). Faulkner's Pantaloon: The Negro Anomaly at the Heart of Go Down, Moses. American Literature, 44(3), 430-44. http://dx.doi.org/10.2307/2924152

Werner, C. (1987). Minstrel Nightmares: Black Dreams of Faulkner's Dreams of Blacks. In Fowler, D., \& Abadie, A. J. (Eds.), Faulkner and Race: Faulkner and Yoknapatawpha 1986 (pp. 35-57). Jackson: University Press of Mississippi.

Wright, R. (1940). Native Son. London: Vintage.

\section{Notes}

${ }^{1}$ Barbara Ladd, for example, observes that Go Down, Moses is the first book in which "Faulkner undertakes a 'direct' and sustained exploration of racial conflict"' (2007, p. 135).

${ }^{2}$ Faulkner talked about "The Bear," the fifth story in the book as part of a novel (Faulkner, 1959, p. 4). At another occasion Faulkner described the book as "simply a collection of short stories" (Meriwether \& Millgate, 1968, p. 54). 
${ }^{3}$ The scarlet letter A, like the ledgers in Ike's case, will be associated with Hawthorne's ancestors' sins as they persecuted women when they acted as judges prosecuting witches and sentenced a number of women to death.

${ }^{4}$ Several critics have questioned the possibility of love between masters and slaves. Angela Davis, for example, argues that there could hardly be a basis of delight, affection and love "as white men, by virtue of their economic position, had unlimited access to Black women's bodies" (1983, p. 26). For a detailed study on love between masters and slaves, see Deborah E. Mc Dowell.

${ }^{5}$ I think it is more accurate to use the word design in relation to old Carothers because he was one of the founding fathers in Jefferson. Sutpen's "design" is not original in the sense that it tries to reproduce what people like old Carothers have achieved before him.

${ }^{6}$ Sophonsiba's subversive act, which is attempted later but without success by Ike's wife, who tries to seduce him sexually to make him reverse his subversive decision and reclaim the heritage which he has repudiated, might shed some light on the role of two white women in race relations within the McCaslin family.

${ }^{7}$ I would like to stress the multiplicity of Ike's sources of knowledge about both his family and their slaves. While I acknowledge the appeal of Godden's and Polk's reading of the ledgers, which also gives some attention to family lore, I would like to stress that they do not seem to give enough importance to Sam Fathers, as a source of information to Ike, which might be justified by their interest in the ledgers mainly. I think that the multiplicity of these sources might add strength to Ike's reading of the ledgers, which they try to discredit as a reconstruction of the ledgers on his part, which is motivated by his desire to lay the blame on his grandfather to avoid conflict with his "homosexual" father (2002, p. 339).

${ }^{8}$ There is, however, a possibility to speculate that the most closely associated house with the McCaslins, that of the Beauchamps in the so called Warwick plantation, which burns down in 1870 when only Hubert Beauchamp and Tennie's great-grandfather lived there, might have been burnt by this ex-slave. This speculation acquires some strength by Tennie's great-grandfather's mysterious disappearance from the text afterwards (Faulkner, 1942, pp. 292-3).

${ }^{9}$ Molly's name is also spelled as Mollie in the last story "Go Down, Moses." I am using one spelling only.

${ }^{10}$ Lucas's suspicions are echoed by black men in Zora Neale Hurston's Their Eyes Were Watching God when they accuse black women of siding with white men against them. They describe the alliance between their women and white men in sexual terms: "Well, you know whut dey say "uh white man uh nigger woman is de freest thing on earth.' Dey do as dey please" (1937, p. 280).

${ }^{11}$ In this process Roth is presented as playing the role of the white master, who, according to the Southern family romance, takes care of his black servants.

${ }^{12}$ In her discussion of Faulkner's treatment of "The Tragic Mulatta," Diane Roberts notes that, in contrast to the mammy, "the young black woman disrupts and confuses the defining binaries of the South: white over black, virgin over whore" (1994, p. 70).

13 The unwillingness of the paper editor to publish Butch's full story is an example of black people's representation in white papers. Black authors such as Richard Wright and Toni Morrison engage more with this representation as they examine how white papers report on crimes committed by black people, like Bigger Thomas in Native Son and Sethe Suggs in Beloved. While Wright quotes extensively from the Tribune, where Bigger is described as "a jungle beast" (1940, p. 309), Morrison does not tell us what is written in the paper clipping which tells the story of Sethe beheading her daughter Beloved, but we know that it has a photo of Sethe. Morrison goes on to describe how white papers engage with black people, and according to her, no ordinary news about black people would qualify to be news in a newspaper. "It would have to be something out of the ordinary—something whitepeople would find interesting" (1987, p. 183).

${ }^{14}$ Glissant concludes that Faulkner's "choice of techniques shows a clarity and honesty ....in one who knows, who admits in effect, that he will never understand either Blacks or Indians and that it would be hateful...to pose as an omniscient narrator or to try to penetrate these minds that are unfathomable to him" (1999, pp. 67-68). 